\title{
JUDICIAL ADMINISTRATION IN A CHANGING SOCIETY - CUSTOMARY COURTS IN WESTERN NIGERIA
}

\author{
By Oluyemi Kayode*
}

Of all the institutions in a society the legal constitutes an area that deserves serious attention; intricately tied to culture as it were, law as a system embraces a wide range of rules regulating behaviours. Thus when viewed from the perspective of social control, the interconnectedness of culture and law becomes clear. It becomes clearer still when such an interplay is being examined in a relatively simple society - such as those that have interested social anthropologists since the inception of their discipline.

We will not now reopen the debate on what the definition of "law" really is: not only because a lot of discussion have been generated by it - right from outstanding jurists like, John Austin ${ }^{1}$, to Roscoe Pound ${ }^{2}$, to anthropologists like Radcliffe-Brown ${ }^{3}$, Schapera ${ }^{4}$, and Evans-Pritchard 5 , but also because it is really not central to our interest in this paper. We would take the position that law constitutes a system of rules and guidelines written or otherwise - that are supposed to guide and regulate interactions, such that its elements are generally acceptable to the entire population, and that in case of infraction, there is an impartial authority to decide on the rights and wrongs of a case, behind which there is a recognised power - formal or informal - to enforce compliance with the decision reached. This represents indeed a broad definition of law and it is predicated on the belief that the concept of law, to be of any universal utility, must take into account that fact of a wide spectrum of rules and sanctions that govern relations in diverse societies. Smith seems to be suggesting this flexible consideration of law when he reminds us that "the doctrine of the rule of law ... imposes on sociologists the important task of formulating culture-free definitions of law and government which may have comparable significance ${ }^{6}$.

In the first section of this paper, we shall discuss the traditional system of justice among the Yoruba, who now constitute the population of Western Nigeria. The second part will be addressed to the evolution of judicial system during colonial administration up to self-government. In the concluding part we shall examine the place and prospects of indigenous judicial arbitration in this part of Nigeria.

\footnotetext{
* The author is a lecturer in the Department of Sociology, University of Ibadan, Nigeria. The financial assistance of a University of Ibadan Senate Research Grant which made this study possible is gratefully acknowledged.

1 John Austin, Lectures on Jurisprudence (1832), 3rd ed. revised (London: J. Murray, 1869).

2 Roscoe Pound, Outlines of Lectures on Jurisprudence (1903), The Spirit of the Common Law (1921), An Introduction to the Philosophy of Law (1922).

3 Radcliffe-Brown, "Primitive Law" in Encyclopedia of the Social Sciences, IX, 1933.

4 I. Schapera, A Handbook of Tswana Law and Custom (Oxford University Press, 1938).

5 Evans-Pritchard, African Political Systems (1940).

$6 \mathrm{M}$. G. Smith, "The Sociological Framework of Law" in Kuper and Kuper (eds.); African Law Adaption and Development (University of California Press, 1965).
} 


\section{The traditional system of justice among the Yoruba}

Organised political government has been the pattern of administration among the Yoruba of Nigeria long before the advent of the British to this part of the world. Unlike many acephalous societies, organised on a "Stateless" basis, the framework of political relationship among the Yoruba was arranged around a "state" framework. As Fadipe has pointed out "the average Yoruba state comprised the capital, generally walled ... together with one or more towns, townlets, farmers "villages" and hamlets whose inhabitants regarded themselves as belonging to one or another of the towns"?.

He goes on to explain that the satelite towns that, with the capital, comprised each state, were either originally settled by people from the capital or subjugated by them through warfare. Essentially however a state among the Yoruba was coterminous with sub-ethnic groups that shared similar linguistic and other characteristics. The political organisation was quite simple, with the village and town chiefs virtually independent in local matters; any matter that involved more than a community usually called for intervention by the authority in the capital. The selection of local chiefs and all relations with other states were exclusively handled by the state cabinet.

As a result of this political set-up and the cultural trait of deferring to elders and seniors in Yoruba society, the individual, in the final analysis, was responsible (or was it subservient?) to the head of his state. To the extent that he did not actually feel the direct impact of the state apparatus, his allegiance to the kingdom was indirect, though nonetheless unquestionable. His family or compound head represented his loyalty to the local chief who in turn symbolised the wishes, aspirations and allegiance of his people to the centre.

The judicial system was organised around this political arrangement; like the collection of revenue and tributes, the dispensation of justice was controlled from the centre through intermediary functionaries. The level of political sophistication was such that there were established avenues for using the state apparatus to seek redress in inter-personal disputes or claims. No individual was expected to take the laws into his own hands by unilaterally asserting his claim or righting any wrong done him.

The procedure for civil and criminal cases was fairly similar except that some "courts" were not competent to deliberate on criminal cases because of their serious nature. The distinction between these two categories of cases appeared quite clear, and as various writers have pointed out, the basis for such a distinction was similar to that operating in Western legal systems ${ }^{8}$. In civil matters litigation would start from the compound - that is if the parties to the case were from the same compound. Civil matters would include cases of debt, matrimonial disputes, rival claims on land, seduction, breach of contract and other matters of a similar nature. The head of the compound constituted the sole judge except in cases which involved more than one compund where the most senior compound head presided along with the other heads of compounds. The essence of this "compound justice" was to enable the head "to keep his people together in a harmonious relationship".

7 H. A. Fadipe, The Sociology of the Yoruba (Ibadan University Press, 1970, p. 200).

$8 \mathrm{H}$. A. Fadipe, op. cit., p. 227; T. O. Elias, The Nature of African Customary Law (Manchestes University Press, 1956, p. $110 \mathrm{ff}$.). 
Apart from being a court of first instance the Tribunal of the Ward Chief also constituted a court of appeal for those not satisfied with judgements handed down by "compound" courts. The field of jurisdiction was much more comprehensive than the latter; it also served as a court of preliminary hearing in criminal matters within its area of operation. The composition of this tribunal would be drawn from the list of senior chiefs in the town or community as the case may be. Above the tribunal of the Ward Chief was the central tribunal whose composition was the same as the council of the state or the cabinet. It was the court of first instance in criminal matters except cases of minor theft which involved persons from the same family. Apart from criminal cases and civil matters which cut across communities or wards, on which the chiefs concerned were unable to arrange a settlement, the central tribunal constituted the final court of appeal for all litigants within a Yoruba state. Fines were usually imposed in civil cases and minor criminal matters; physical punishment was common for those adjuged guilty on serious criminal offences - flogging, mutilation, castration for those guilty of incest, and death for those against whom the charge of murder was successfully proved. As much as possible however the option of fine was most commonly used for the simple reason that it generated added revenue for the state. Procedure in criminal and civil cases was the same, except that in the former, the judges themselves were the prosecutors. The parties involved were allowed to state their sides to the matter under adjudication and to call witnesses who were not supposed to be present when the plaintiff and defendant took the witness box. Oath-taking before evidence was uncommon, though persons who so elected, were allowed to be sworn.

Below is a diagramatic representation of the traditional judicial system in a "typical" Yoruba state - variations between various states or kingdoms were generally on the level of details.

FIG. 1 System of Appeal in the Yoruba Traditional Judicial Set-up ${ }^{9}$

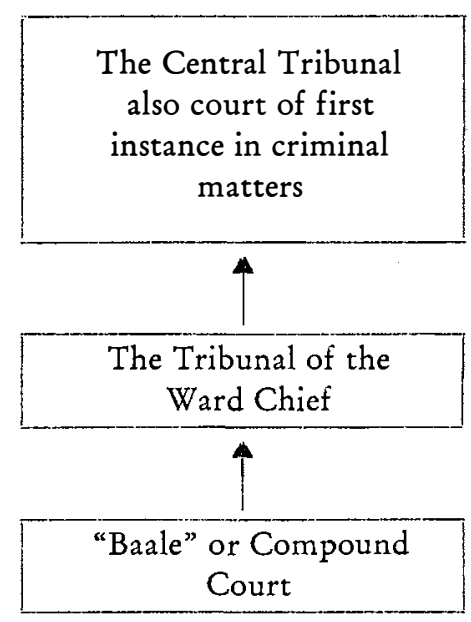

9 Based on N. A. Fadipe, op. cit., pp. 228-231. 
In a centralised political system like that in Yoruba states, the execution of judgement did not present much problem to the authorities. In a vast majority of cases, the guilty party complied with the court decision; in the event of a noncompliance however, the law was enforced by appointed officials - with the weight of the institutionalised military and administrative machinery behind them ${ }^{10}$. It has also been pointed out that the main preoccupation of the "judges" who sat in judgement over others was to arrive at a reconciliation of the parties to a dispute; in essence the objective of the system was "peace-keeping" - intervening and arbitrating in misunderstandings, rival claims and other disputes with could impair social solidarity or degenerate into serious breaches of community harmony. This is not however to imply the non-existence of reparatory and retributive justice; no doubt retribution came handy as an instrument of deterrence, while reparation provided compensation or a restoration of status quo ante as it were, for the injured party. Apart from the suggestion that the traditional judicial system strove to ensure interpersonal and inter-group spirit of communality, parties or potential parties to disputes were assured cheap and quick - nontheless - fair justice.

\section{Judicial Administration During Colonial Rule}

Colonial rule did not effectively start in the present area defined as Western State of Nigeria until 1893 when the then colonial government in Lagos annexed Egbaland and signed similar treaties with Alafin of Oyo and Ibadan Chiefs. Prior to this the Supreme Court of Lagos had been established in 1876 as: "a superior Court of Record with all the jurisdiction and powers vested in Her Majesty's High Court of Justice in England, the law to be administered by it being defined as the common law, the doctrines of equity, and the statutes of general application which were in force in England on July 24, 1874, so far as applicable11."

Built into this Supreme Court Ordinance was the acceptance of the relevance and validity of "native" customs and rules as these regulated social interaction and transactions among the indigenous population. There was the proviso, however, that such customs or rules to be so accorded recognition must not be repugnant to natural justice, equity and good conscience. As Keay and Richardson, among others, have noted, no general principle or guidelines for the interpretation of this "repugnancy clause" has since been propounded, although decided cases have made it quite clear that any customs or rules implying slavery or servile status are repugnant. Moreover, such customs or rules must not be incompatible with any local statutes; thus once a law existed on the statute books, it would have superceded any customary rule in that sphere of legal jurisdiction.

Within these guidelines, administration of justice was largely left in the hands of traditional leaders in the various areas; the head chief of each town presided over the local court, and appeals laid, as during pre-British days, to the principal ruler in the sub-Yoruba group. Such natural rulers, in 1899, were the Alafin of Oyo,

10 T. O. Elias, op. cit., p. 263.

11 E. A. Keay \& S. S. Richardson, The Native and Customary Courts of Nigeria (London, Sweet \& Maxwell, Lagos, African Universities Press, 1966). 
Oni of Ife, Owa of Ilesa and the Bashorun of Ibadan ${ }^{12}$. The tension generated by the "imposition" of constraints by British officials on the delivery of justice in the traditional Yoruba style began to be felt. During that year (1899) eighteen "witches" accused of stopping rain were tried by the local chiefs and made to die through the "Obo" ordeal. The following year in Ibadan, two burglars were tried by the appropriate chiefs, condemned and executed ${ }^{13}$. The authorities in both localities, no doubt aware of the fact that the final decision "in matters of life and death rests with $\mathrm{H}$. E. the Governor alone ${ }^{14}$ ", were beginning to demonstrate signs of impatience with the requirements of British style of justice.

The 1918 Native Courts Ordinance which replaced that of 1914 was specifically fashioned after the system that was already in practice in the North since $1906^{15}$. The ordinance provided for four grades of native courts to be styled A, B, C, D, each with stated powers and jurisdictions; they were supposed to have jurisdiction in those cases where all the parties belonged to a class of persons who had ordinarily been subject to the jurisdiction of native tribunals. They were empowered to try cases involving native law and custom prevailing in their respective areas of jurisdiction. The Grade A Courts had full judicial power in both civil and criminal matters; they could also hand down death sentences though actual execution must receive the approval of the Governor. Though the other grades had jurisdiction in criminal cases, their powers in such cases were restricted progressively as one moved from the superior to the inferior courts with the Grade D court limited to

"civil cases in which the debt, demand or damages did not exceed ... £5, and criminal cases wherein the offence could be adequately punished by imprisonment not exceeding three months, twelve lashes, or a fine not exceeding $£ 5$ or the equivalent by native law and custom ${ }^{16}$."

By the grace of the Governor, the courts could also be empowered to administer statute law: thus by 1928, all native courts were granted powers under the Native Revenue Ordinance ${ }^{17}$. Other such powers granted included those under the Building lines Ordinance ${ }^{18}$ given to all southern courts, and the power vested in Ake Grade A Court under the Motor Traffic Ordinance ${ }^{19}$.

All the various grades of court during this period were manned entirely by local chiefs who by the fact of their traditional position in the community were deemed to be very knowledgeable in the customary law of their respective areas. Such were in fact their presumed knowledge of the law that no formal proof of the law was required in these native courts; the only exception with regards to this presidency of native courts was the Abeokuta Grade A Customary Court which until 1958 was the only one presided over by a barrister assisted by a number of customary law assessors ${ }^{20}$.

12 See Annual Report, Lagos Colony, 1899.

13 Annual Report, Lagos Colony, 1900-1901.

14 Ibid.

15 Annual Reports (Northern Nigeria) 1905-1906.

16 E. A. Kea \& S. S. Richardson, op. cit., p. 29.

17 Laws of Nigeria, 1928 , p. 330.

18 Laws of Nigeria, 1933, p. 641.

19 Laws of Nigeria, 1936, pp. B. 5 and B. 126

20 O. Awolowo, Path to Nigerian Freedom (Faber \& Faber Ltd., 1947, p. 89). 
Fig. 2: System of Appeal from Native Courts

Prior to Self-government in Western Nigeria

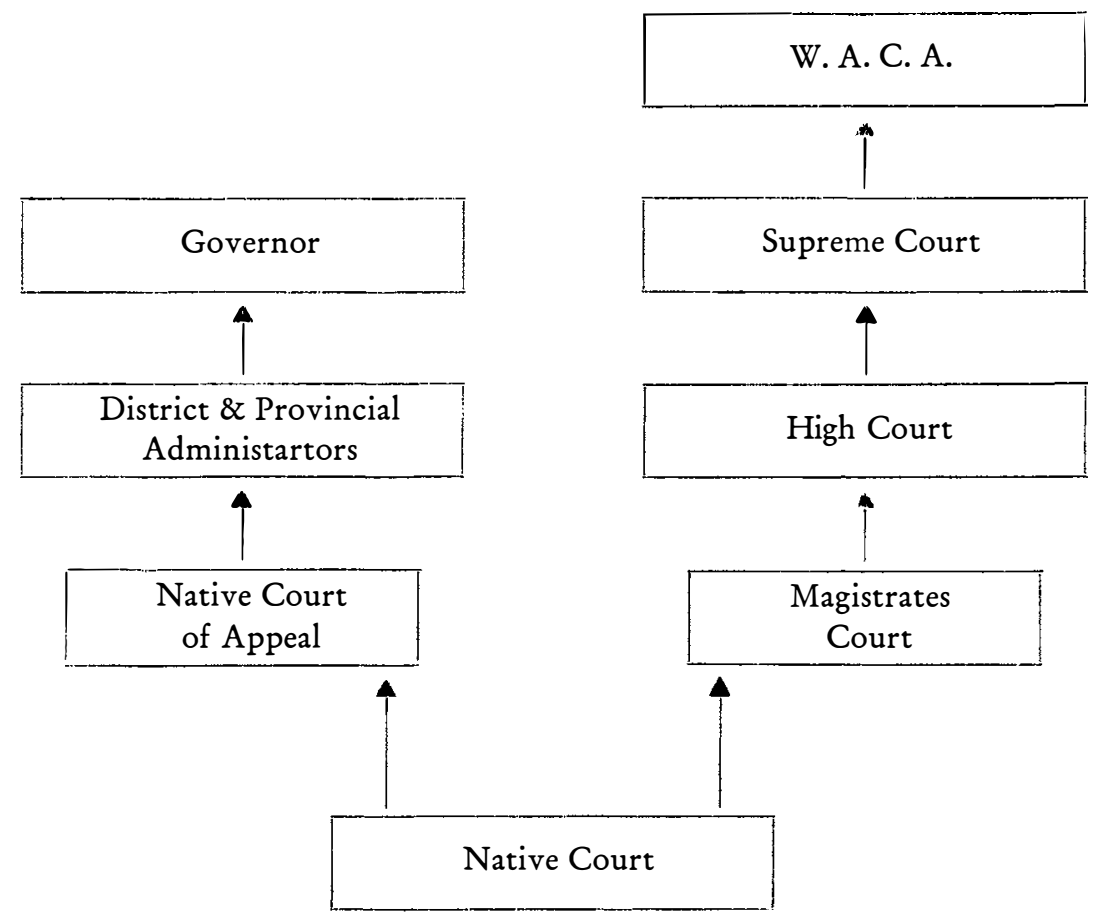

Given the bifurcated or "parallel" nature of the appeal system, cases emanating from native courts in the first instance could terminate either with the Governor or in the West African Court of Appeal; where a case was finally settled however depended on the instrument establishing the particular native court of first hearing. Since there were very few native courts of Appeal - only 63 compared with about 584 native courts in $1951^{21}$ - and limited number of courts for which appeals could go directly to the Magistrate's court, the bulk of case reviews was handled by administrative officers who wielded a considerable amount of supervisory power and control over native courts. Desperate litigants usually pressed their cases beyond administrators to the Regional Governor.

The major instrument establishing this system of appeal was the Native Courts Ordinance of 1933, and though apparently straightforward, the implementations of the Ordinance established a series of complicated systems of appeal.

\section{Native Courts since Self-government}

The West Africa Court of Appeal judgement of 1947 in the case of Tsofo Gubba V. Gwandu Native Authority ruled that the criminal Code was directly applicable to Native Courts and that "therefore whenever a native court tried any person for any offence which was defined in the criminal code, it was bound

21 Report of the Native Courts Commission of Inquiry, 1952, pp. 9-11. 
to follow the code and not native law and custom 22 ". This ruling among other factors, led to the Brooke Commission of Inquiry set up in 1948 to reappraise the native court policy. It was felt that a clearer definition of the law to be administered by various courts was needed; so too the system of appeal from such courts. Although the Commission Report advised that its recommendations be uniformly applied throughout the country, the Order-in-council of 1954 establishing the Federation of Nigeria provided native courts as a residual matter that could only be legislated by the Regions. The Report recommended that the term "customary" should replace "native" in the description of the courts and the law they administer. This was reflected in the 1957 Western Region legislation.

The Customary Courts Law, 1957 was a sequel to the Brooke Commission Report. The law provided for four grades of courts - A, B, C, D with varying amounts of jurisdiction. The civil jurisdiction of a chief customary court President of a Grade A Court covers estate property, damages, demands and so on of up to N 1000 (one thousand naira) cash values while that of Grade D was fixed at N 50.

The Minister of Justice had the power to establish a court in any part of the region on the basis of some criteria which include the following: a large enough population to justify such a court, accessibility to the regional headquarters to facilitate supervision; and evidence that the local council concerned can finance the proposed court.

With the exception of Grade A judges who were under the control and supervision of the Judicial Service Commission ${ }^{23}$, the appointment and dismissal of Customary Court judges became the responsibility of the Local Government Service Board. The law also stipulated that all presidents of Grade A and B courts must be literate in the English Language. The law made it possible for legal practitioners to appear in Grade A courts - all of which were later presided over by qualified lawyers.

Contrary to the Brooke Commission recommendation the power of review hitherto vested in administrative officers was replaced with a right of appeal as set out in the following diagram.

22 E. A. Keay \& S. S. Richardson, op. cit., p. 48.

$23 \mathrm{~F}$. A. Ajayi, The Interaction of English Law with Customary Law in Western Nigeria (Journal of African Law, Vol. 4, 1960, p. 44). 
Fig. 3: System of Appeal as Set Out by

The Customary Courts Law of 1957

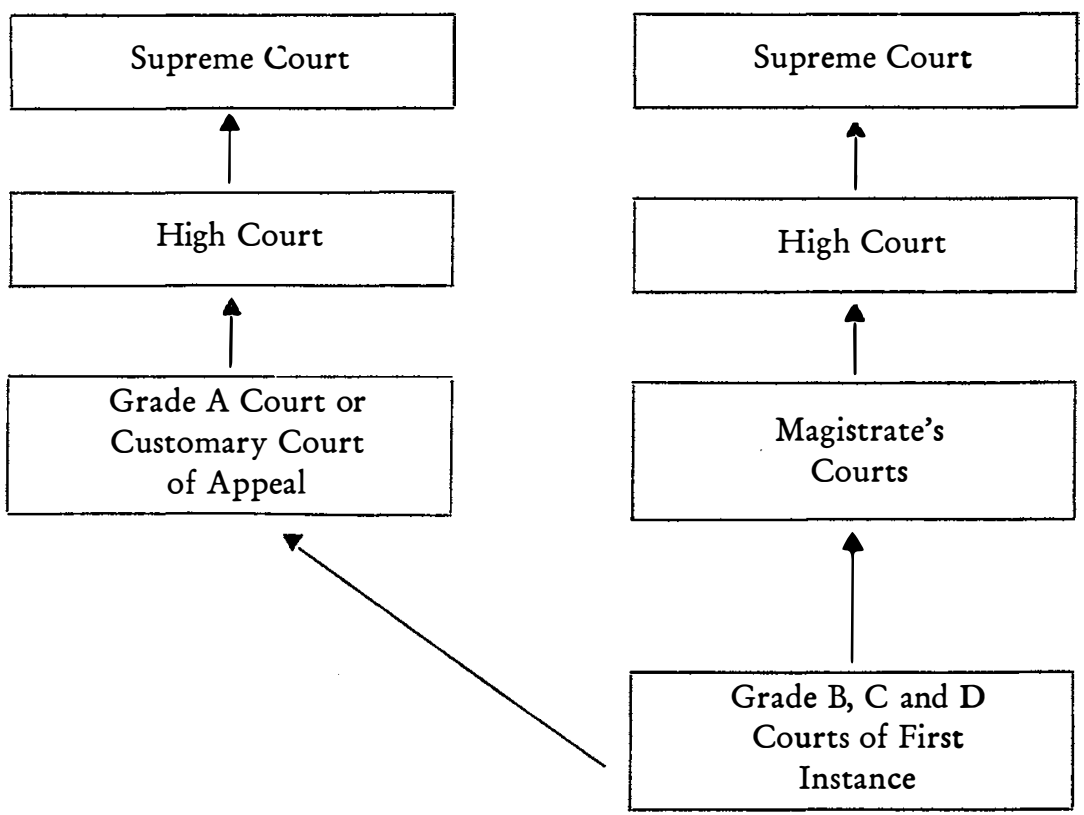

The 1957 Law thus altered the bifurcated appeal system of colonial days and introduced an integrated system whereby all cases that did not end in the appropriate customary court can be heard in the English-type court terminating possibly in the Supreme Court of Nigeria. The total number of courts has dwindled over the years; in 1958, there were 468 Customary Courts in the state 24. Though the figure rose to 630 by 1962 , today there are only 428 Customary Courts distributed as follows:

Grade A - 11 courts

Grade B - 56 courts

Grade C -361 courts

This decrease in the total number of courts is one direct consequence of continuing attempts to reconstitute and restructure the system of customary courts; they have been regrouped in areas where there were unnecessary overlaps.

The calibre of court personnel has also greatly improved, with all Grade A Courts and most, if not all Grade B Courts presided over by qualified barristers. With Grade $\mathrm{D}$ Courts having been abolished, only $\mathrm{C}$ courts are now manned by local chiefs and influential persons who are supposed to be knowledgeable in the tradition and customs of the community in which they serve. In many of the communities, chiefs preside over courts as part of the traditional roles attached to their chief-taincy titles. This has brought about the intolerable situation whereby men too old to preside over judicial proceedings have to. The case of some court members in Oyo and Ila-Orangun who were well over a hundred years old at the

24 E. A. Keay \& S. S. Richardson, op. cit., p. 98. 
time of our interview with Ministry of Justice Officials attest this problem: one of the chiefs, the "Obala" of Ila-Orangun had even asked to be relieved of this assignment "forced" on him, as it were, by tradition.

The influence of English Law on the Native (customary) Law system which started during the colonial era has continued into this period. It has been argued, though, that such erosion of traditional judicial system has been restricted to the field of practice and procedure rather than in the field of substantive law itself ${ }^{25}$, but one must take cognisance of the amount of statutes and bye-laws that have been passed to preempt the sphere of customary law.

From the data available to us there is no doubting the "popularity" of customary courts as resort for seeking judicial redress. Table 1 contains information on the number of cases brought before the three segments of the Western State judiciary during a five-year period. Over 70 per cent of criminal cases came before customary courts while a greater proportion - 93 per cent of all civil cases - was handled by Customary Courts. Preliminary figures from an on-going research by the author show that most criminal cases that come before customary courts involve assault, stealing and sanitary offences. It should be mentioned at this point that capital and other major infractions of the law-treason, sedition, rape, homicide and so on are excluded from the jurisdiction of customary courts ${ }^{26}$.

Table 1

Court Returns for Civil and Criminal Cases in Western Nigeria 1969-1973*

\begin{tabular}{ccccccccc}
\hline Year & \multicolumn{3}{c}{ Number of Civil Cases Filed } & \multicolumn{3}{c}{ Number of Criminal Cases Filed } \\
\hline & $\begin{array}{c}\text { High } \\
\text { Courts }\end{array}$ & $\begin{array}{c}\text { Ma- } \\
\text { gistrate } \\
\text { Courts }\end{array}$ & $\begin{array}{c}\text { Custom- } \\
\text { ary } \\
\text { Courts }\end{array}$ & Total & $\begin{array}{c}\text { High } \\
\text { Courts }\end{array}$ & $\begin{array}{c}\text { Ma- } \\
\text { gistrate } \\
\text { Courts }\end{array}$ & $\begin{array}{c}\text { Custom- } \\
\text { ary } \\
\text { Courts }\end{array}$ & Total \\
\cline { 2 - 10 } & 702 & 2675 & 38035 & 41412 & 207 & 5593 & 14247 & 20047 \\
1970 & 909 & 2515 & 40666 & 44090 & 313 & 4955 & 11607 & 16875 \\
1971 & 886 & 1698 & 40471 & 43055 & 202 & 5439 & 14374 & 20015 \\
1972 & 920 & 1929 & 44317 & 47166 & 180 & 6164 & 15497 & 21841 \\
1973 & 1037 & 3175 & n.a & $?$ & 194 & 6392 & n.a & $?$ \\
\hline
\end{tabular}

\footnotetext{
* Sources:

1. Figures on High Courts and Magistrate Courts were manually extracted by Mr. I. O. Adelola, a graduate student in Sociology, University of Ibadan.

2. Figures for Customary Courts were taken from "Digest of Local Government Statistics" published by the Western State of Nigeria.

n. a. Mizans information was not available.

25 F. A. Ajayi, op. cit, p. 42 f.

26 See African Conference on Local Courts and Customary Law (Record of Proceedings of the conference held in Dar-Es-Salam, Tanzania, 1963, p. 80

27 A. H. Allot, “The future of African Law" in Kuper \& Kuper (eds.) op. cit.
} 


\section{CONCLUSION:}

\section{The Future of Customary Courts}

Apart from their historical and sociological significance, the pervasive position occupied by Customary Courts in the dispensation of justice in the Western State of Nigeria is obvious from Table 1. The "popularity" of this type of courts, which cannot be overemphasised, stems partly from some of its virtues vis-a-vis the imposed legal system. Allott ${ }^{27}$ has discussed this somewhere else: such advantages of customary courts include the localness and speed with which justice was administered, the simplicity and flexibility of the procedure and relatively low cost of obtaining judicial intervention. Also discussing the same subject, Richardson alludes to the fact that "no Nigerian has to travel far to find a customary court with jurisdiction over almost any cause or matter"28".

The "professionalisation" of certain grades of Customary Courts - A and many $B$ courts now presided over by lawyers and before which legal practitioners are free to appear - in the state has detracted to a certain extent from the advantages offered by resort to courts of this type. However, since the overwhelming majority of Customary Courts in the state do not fall under the categories of A and $\mathrm{B}$, much of the virtues of traditional courts still remain. It is against this background that the reform of the system of Customary Courts in the State could be anticipated. There is now no need to revert to the parallel arrangement of the judicial system that preceded 1957; in fact the integrated pattern as it now operates gives a sense of unity to the functioning of the judiciary and allows for attempts at comphrehensive and far-reaching policy control of all the facets of judicial intervention in the State.

One reform that is being contemplated has to do with the membership of Grade B Courts; of now most of them have sole presidents, mostly lawyers. It is being argued that in keeping with Yoruba tradition, customary courts should be designed as multi-member tribunals. In the question of custom, no single chief or elder should be assumed to have the correct interpretation of an event or points to a dispute; a tribunal made up of local chiefs and elders appears more in keeping with the Yoruba belief that "two heads are better than one". It becomes much more so when it comes to the interpretation of customs that are as a result of "westernisation" and institutional changes in the structure of the society becoming more and more difficult to prove or ascertain.

Closely related to this is the idea of imposing an age-limit on those who preside in these courts; reference was made to this earlier. Since membership in certain types of local courts are tied to chieftaincy titles, a problem arises when incumbents of such offices become very old but still, as a matter of tradition, have to continue to sit in the appropriate courts. It is understood that the state Ministry of Justice is devising ways of dealing with the age problem while at the same time not robbing the serving chieftaincy family of its seat in the local court in question. The age limit being proposed is 70 years.

Most of the 428 Customary Courts in the State do not have court houses as we know them; they sit in town halls, community centres, abandoned school buildings and in dilapidated unused private buildings. The physical and environmental

28 S. S. Richardson, "Whither Lay Justice in Africa" in Max. Gluckman (ed.), Ideas and Procedures in African Customary Law (International African Institute, 1969). 
condition in which the courts hold their sessions are not the best for the purpose; there are no witness boxes, and not enough seats for members of the public who are interested in "watching" justice being done. They lack virtually all modern conveniences - most for example have no toilet facilities attached to them. It is hoped that the state government would embark on a conscious policy of housing customary courts in buildings that will provide the kind of atmosphere in which all the facts to a dispute can be gathered and used in the interest of justice.

The financial control exercised by local councils on customary courts has served to unduly constrain the independence of the courts; there have been cases of victimisation of court presidents who passed judgements not acceptable to local council functionaries; in a particular instance, a council, after such a ruling, suddenly transferred the court clerk to another assignment thus incapacitating the court in question. Salaries of court members have also been known to have been stopped at will by the appropriate local councils. It is hoped that this everpresent power of councils to strangulate customary courts is not allowed to persist. This fear could be removed by establishing a single state-wide body to which all fines and monies due to customary courts are paid and which in turn disburses the fund to court functionaries throughout the state. The body should also be responsible for the deployment of various categories of court staff.

One final suggestion for improving and invigorating Customary Courts has to do with the codification of customs or customary "laws". This is an area in which there is not much agreement: some legal scholars have argued that the idea of codification itself runs counter to the very nature of customary law ${ }^{29}$. The main argument against codification is the rigidity it could introduce into customary law: this fear stems from the fact that courts themselves believe that customs do change as circumstances alter and that each time any custom is invoked, it has to be proved as valid. Handing down judgement in an appeal case the then Chief Justice of Nigeria said among other things that: also it is a well-known fact that in recent years customs have changed rapidly in Nigeria, and what was custom twenty years ago has ceased to be the custom of the people ${ }^{30}$.

It could be argued that the accepted customs of a community on certain matters, inheritance, land tenure etc. should be recorded so that these could be used as precedents in adjudicating fresh disputes; this could be achieved short of codification. The argument of rigidity that could be introduced by written customary laws is not as strong as it sounds; after all law is a living subject which will continue to develop and change: when such changes necessitate a reconsideration of particular aspects of the law, amendments could be introduced to achieve this. Much as one might disagree with Elias' position that "the future development of the various bodies of customary law should ... be left to textbook writers" and that "rash schemes of codification in the field of customary law at this stage of our development should be eschewed ${ }^{31}$ ", the fact that courts at present apply to the disputes before them precedents established in similar circumstances or situations takes a lot of heat out of the rigidity argument.

29 E. Cotran, "Integration of Courts and Application of Customary Law in Tanganyika" in East African Law Journal 108, 117, 1965, pp. 27-28; O. Akanki, "Proof of Customary Law in Nigerian Courts" in The Nigerian Law Journal, Vol. 4, 1970, p. 31

30 Judgement delivered in Apoesho V. Chief Odelo of Ilesha, 1964, M. L. R. 8 at p. 11.

31 T. O. Elisa, Law in a Developing Society (Inaugural Lecture delivered at the University of Lagos) 1969, p. 25 . 
Without taking the necessary cognisance of the various customs accepted and acceptable to the various sections of the Western State of Nigeria - in a written form - the fear of extinction - albeit a graudal one - becomes very real to those who see a lot that should be preserved in the very rich traditional heritage of a people who have found their institutions grappling with the determined challenge of change. The extent to which the customary laws of a state or region can withstand the constant onslaught of alien values could very well determine the rate at which the entire institutional arrangements in that society would be submerged if at all, by foreign definitions and perceptions of events and values. It is within this context that the significance of viable customary courts should be understood, and the necessity for their constant invigoration appreciated.

\title{
REFERENCES
}

\author{
"Answers to United Nations Questionnaire. Persons considered to be born out of wedlock." Typescript \\ copy from Attorney General's Office. \\ Baker, T. and Bird, M. "Urbanization and the position of women" in special number on \\ Urbanism in West Africa, ed. K. Little, Sociological Review, Vol. 7, No. 1, \\ New Series 1959. \\ Bangurah, J. \\ "Born to be outcasts". Flamingo, Sierra Leone. Vol. 4 No. 11, August 1965 \\ Barnes, J. A. \\ Edition. \\ Collier, G. \\ "The politics of law" in Man in Africa, ed. M. Douglas and P. Kaberry, \\ London, 1969. \\ Collier, G. $\quad$ Sierra \\ Crabtree, A. I. \\ "Marriage and family life among educated Africans in the urban areas of \\ the Gold Coast". Unpublished M.Sc. Thesis, London University, 1950. \\ DAILY MAIL \\ Harrell-Bond, B. E. \\ 31 August, 1965, 3 September 1965. \\ Harrell-Bond, B. E. \\ "Modern marriage in Sierra Leone: a study of the professional group." \\ Mouton, 1975 (forthcoming). \\ "Survey' research in a study of marriage" in Solving Problems of Survey \\ Research in Africa, ed. O'Barr Spain and Sessler, Chicago, 1972. \\ "Some influences on attitudes about family limitation and on the use of \\ contraceptives among the professional group in Sierra Leone' in Popula- \\ tion Growth - Socio-economic Change in West Africa, ed J. C. Caldwell, \\ N. O. Addo, S. K. Gaise, A. Igun, P. O. Olusanga, Columbia University \\ Press 1974. \\ Izzett, A. \\ "Family life among the Yoruba in Lagos, Nigeria" in Social Change in \\ Modern Africa, ed. A. W. Southall, London, 1961. \\ Jellicoe, G. \\ Kilson, M. \\ Koelle, S. W. \\ 1955. \\ Political Change in a West African State. Cambridgc, Mass., 1966. \\ Polyglotta Africana, London, 1851. \\ Laws of Sierra Leone, 1960 Edition. \\ The Mende of Sierra Leone (First Edition, 1951). London, 1967. \\ Little, K. L. \\ Little, K. L. \\ and Price, A. \\ Moore, S. F. \\ "Some trends in modern marriage among West Africans". Africa, Vol. 37, \\ No. 4, October $196 \%$. \\ "Law and Anthropology" in Biennial Review of Anthropology, ed. B. J. \\ Sicgel, Stanford, 1970. \\ Province of Freedom, London, 1969. \\ Peterson, I. \\ Pospisil, L. \\ Saario, U. U. \\ Anthropology of Law. London, New York, 1971. \\ "A Study of discrimination against persons born out of wcdlock". Sub- \\ Commission on Prevention of Discrimination and Protection of Minorities, \\ United Nations, New York, 1967. \\ Smart, H. M. J. \\ "Inheritance to property in Sierra Leone: an analysis of the law and \\ problems involved". Sierra Leone Studies, No. 14, January 1969. \\ "Sierra Leone" in Allott's Judical and Legal System of Africa, ed. A. N. \\ Allott, London 1970.
}

